\title{
Topological 3D Model of the Functioning of a Dynamic System - Cognitive Estimation of Complexity
}

\author{
V.P. Mygal*, G.V. Mygal \\ National Aerospace University "Kharkiv Aviation Institute”, 17, Chkalova St., 61070 Kharkiv, Ukraine
}

(Received 12 April 2021; revised manuscript received 03 August 2021; published online 20 August 2021)

\begin{abstract}
The article is devoted to the complexity of modeling the functioning of dynamic systems of various nature (sensors, detectors, intelligent materials, and other sources of information). Environmental or activity stressors increase the static complexity of information sources, resulting in dynamic complexity. Information about this is contained in the structure of induced relations, the latent complexity of which limits the ability to predict the functioning of a dynamic system in real time. The purpose of the work is cognitive visualization of the functioning of various sources of information. Morphologically different dynamical systems functionally obey the same extreme principles of physics and are studied by dynamic and statistically methods. Their complementarity made it possible to unify the reconstruction of a three-dimensional (3D) topological model of the functioning of an information source from the measured fractal signal. It was found that the latent structure of the signal is determined by spatial inhomogeneities, which generate temporary inhomogeneities in the information source and transmission environment. Stress factors increase the complexity of spatio-temporal signatures, which makes it possible to estimate the complexity of their configurations by increasing the number of components and the area covered. Therefore, the structure of a fractal signal can be analyzed in real time using additional probabilistic and deterministic methods. The creation of an atlas of fractal signal signatures simplifies the identification and classification of information sources of various nature. Its use will reduce cognitive problems associated with complexity and expand the set of predictive analytics tools. Visualization of latent spatio-temporal features of electrophysiological signals demonstrates the advantages and validity of cognitive visualization of the functioning of different subsystems of the human body.
\end{abstract}

Keywords: Dynamic complexity, Fractal signals, Hidden structure, Topological models, Spatio-temporal signatures.

DOI: 10.21272/jnep.13(4).04023

PACS number: 05.10. - a

\section{INTRODUCTION}

Digitalization and automation of complex dynamic systems (energy, transport, etc.) increase the number of information sources (sensors, detectors, spectrometers, fractal signals, etc.). This, as well as the heterogeneity of the information transmission environment, increases the dynamic complexity of a system and creates time delays. There are systemic problems in ensuring information (biological, physical) safety [1]. In difficult conditions, the safety, reliability and stability of the functioning of dynamic systems largely determine the cognitive aspects of human interaction with a machine (computer, information system and robot) [2]. They are associated with the diversity of information sources in complex dynamic systems, as well as with the difference in the methods of processing information flows and types of its visualization.

Visualization technology affects human thinking [3]. In particular, the average person can keep seven plus or minus two different objects in RAM [4]. Cognitive problems increase when exposed to external and internal stressors, and the ratio of controlled elements reaches 5/9. The likelihood of human error increases the individuality of the perception of the diversity of information flows and the presence of local distortions in them. All of the above limits the possibilities of modeling the functioning of dynamic systems and is the main cause of systemic problems. Consequently, when modeling the functioning of dynamic systems in diffi- cult conditions, it is necessary to take into account the cognitive and ergonomic aspects of human-computer interaction.

The impact of stress factors of the environment and activity is most manifested in the individuality of human-computer interaction. This is facilitated by the use of various definitions of information and its measures according to Wiener (Shannon, Kolmogorov, etc.) [5]. In different subject areas, entropies are used (Boltzmann, Shannon, Kolmogorov, Rainier, etc.), as well as the same terms, patterns, etc., whose semantic definitions are different.

Therefore, engineers, programmers, physicists, biophysicists, etc. sometimes do not understand each other. The manifestation of cognitive problems also contributes to:

- growth of information complexity;

- differentiation of scientific knowledge;

- variety of criteria and concepts.

Under the influence of stress factors, heterogeneities arise in self-structured smart materials (sensors and other information sources). They cause many local distortions in the information flow, in the nature of the distribution of which cognitive information is hidden. However, when processing the information stream, distortions are smoothed out, which limits the possibilities of digital modeling and cognitive computing. In addition, K. Gödel's completeness theorems indicate the limits of computability. Therefore, when modeling

\footnotetext{
*valeriymygal@gmail.com
} 
the functioning of self-organized dynamic systems (biological, physical and chemical), it is necessary to highlight cognitive information that objectively reflects the functional state of self-organized objects, including the state of a person. The purpose of the work is cognitive visualization of topological models of the functioning of self-organized dynamic systems.

The object of study is the complexity of the structural properties of information flows.

The subject of study is the topological models of fractal signals of different nature.

To achieve the goal, it is important to link the structure of an information flow with its individual characteristics, which follows from the generalization of the ideas of nano-, bio-, information and cognitive technologies [6]. Natural and artificial 3D structures (superlattices, etc.) with unique temporal and spatial characteristics have been created using 3D technologies at the nanoscale level. And this means the fundamental possibility of solving the inverse problem - the reconstruction of a topological 3D model of functioning from a fractal time signal (digitized information flow). At the same time, the individuality of the functioning of information sources under the influence of stress factors is due to the induced heterogeneities of different nature. They create local distortions of information flows in which cognitive information is hidden.

\section{PROBLEM STATEMENT}

The impact of stress factors on self-organized environments (sensors, the human body, and other sources of information) increases the number of information sources included in the dynamic system, and the number of connections between them. This increases the statistical complexity that is associated with induced inhomogeneities. Therefore, cognitive information is hidden in the nature of the distribution of local distortions of the information flow. The induced spatial and temporal relationships can be analyzed from different angles of view using different entropies (Shannon, Kolmogorov, Rainier etc.) and fractal dimensions (Fig. 1).



Fig. 1 - Statistical complexity induced by spatial and temporal inhomogeneities

A variety of induced relationships between information sources can be analyzed using the Shannon, Kolmogorov entropies and fractal dimension. However, the measure of quantitative diversity of the functional is the Rainier entropy, which most reflects the statistical complexity. It summarizes dynamic and statistical methods for investigating both spatial and temporal ordering. In our opinion, the reason for the dynamic similarity of the induced processes of different nature is the self-organization of inhomogeneities, which counteracts external influences [7]. This is a manifestation of the Le Chatelier-Brown principle, as well as self-organized criticality.

The induced heterogeneities determine the fine structure of information flows of various nature. Therefore, visualization of not only the coarse (dynamic), but also the fine (informational) structure of the information flow expands the possibilities of topological modeling of the functioning of the information source. Latent interrelationships of spatial and temporal heterogeneities of different scales are described by complementary extreme principles of natural science (principles of least action and least time, etc.). However, to visualize the structural properties of information flows, a unifying idea is needed.

\section{REVIEW OF THE LITERATURE}

The role of a "generator of new ideas" in natural science has always been played by geometrization and fundamental principles [7]. Therefore, to identify cognitive information, it is important to combine the follow- 
ing ideas:

- spatio-temporal ordering of the signal structure, which is important for cybernetics and synergetics;

- reconstruction of the model from a one-dimensional measured signal (Packard, 1980 [8]), which was formalized by Takens [9];

- computer modeling of connections, feedback loops and response delays in system dynamics [10].

Their systemic analysis leads to the connection between the individuality of the functioning and local distortions of the information flow. Information about the individual characteristics of the flow is hidden in the structure of the relationship between the induced spatial and temporal inhomogeneities.

Visualization of the fine structure can be carried out within the framework of an interdisciplinary approach to the research of the individuality of objects of animate and inanimate nature, based on the ideas of D. Maxwell and R. di Bartini about the possibility of an LT-system of physical quantities [11]. This allowed R. di Bartini to carry out the geometrization of physical quantities, writing them in the form $\left[L_{l} T_{k}\right]$, where $l+k \leq 3$ ( $l, k$ are integers). Generalization of these ideas and principles of system dynamics made it possible to analyze signals from different sources of information (sensors, spectrometers, electrophysiological signals of a person, etc.) in the space of dynamic events. Each point of this space displays an event, the probability of which is determined by the product of the state $X(t)$ by the speed $d X(t) / d t$ and the acceleration $d^{2} X(t) / d t^{2}$.

On the other hand, the information content of the space of dynamic events follows from the extreme principles of natural science. Their versatility, complementarity and significance are emphasized in works [2024]. This allows you to identify cognitive information by visualizing the dynamics of different information flows (scalar time series) in one space. So, the state $X(t)$, the rate of its change $d X(t) / d t$, and the acceleration $d^{2} X(t) / d t^{2}$ are included in different formulations of the extreme principles of mechanics. For topological modeling of the functioning of dynamic systems, the following are important:

- complementarity of the principles of least action (Hamilton and A. Hertz) and the principles of biomimicry that underlie natural phenomena;

- geometrization of the Jacobi principle of least action in the form of a geodesic curve;

- energetic interpretation of the Gauss principle of least compulsion and its connection with the theorem of E. Noether.

The connection of these principles with biomimicry underlies the ergonomic laws of mutual adaptation and transformation [25].

\section{MATERIALS AND METHODS}

The functioning of the dynamic system was simulated in the space of dynamic events (state-speedacceleration) [19]. The original algorithm for calculating the probability of an event is developed on the basis of complementary extreme principles of natural science. The cycle of calculating the probability of each event includes the natural decomposition of the signal into opposite dynamic components. A closed sequence of components forms a cycle of functioning in the space of dynamic events.

A new approach to modeling was tested on signals of sensors (detectors and other information sources). We also studied changes in the latent structure of electrophysiological signals (ECG, EEG, EOG, etc.) under the influence of stress factors. All signals were processed using well-known software packages (Matlab, Origin, etc.) and original algorithms. Each point with coordinates $\left\{X, d X / d t, d^{2} X / d t^{2}\right\}$ in the space of dynamic events reflects the probability of the $i$-th event, which was determined in the computational cycle.

In the process of cyclic computation of a sequence of dynamic events, the scalar time series $X(t)$ (digitized cardiac signal, sensor response, sensor characteristic, etc.) is transformed into a cycle of functioning. It is a geometric interpretation of two formulations of the principle of least action. On the one hand, it follows from the Jacobi principle that the cycle of functioning (trajectory) is a geodesic (topological) curve. On the other hand, the trajectory reflects the principle of least curvature or length Hertza.

In a new approach to the reconstruction of a topological 3D model of functioning from a measured time signal, its natural spatial and temporal decomposition is key. So, geometrically ordered areas correspond to a certain time interval between dynamic events. Therefore, the 3D model reflects the relationship between spatial and temporal scaling. So, by changing the sampling frequency when digitizing an analog signal, it is possible to reveal the features of the latent structure of the signal at different scale levels. At the same time, the change in the time interval between events in the configuration components reflects Fermat's principle of least time, which confirms the complementarity of the extreme principles of natural science.

Thus, a new approach to modeling the functioning of an information source is based on a) reconstruction of a topological 3D model from a measured fractal signal; b) natural decomposition into opposite components and the subsequent determination of the degree of their dynamic balance, c) system analysis of orthogonal projections of a 3D model, the configurations of which are spatio-temporal signatures of the $1^{\text {st }}$ and $2^{\text {nd }}$ orders.

\section{EXPERIMENTS}

The possibilities of a new method will be illustrated by an example of a digitized electrocardiogram, which is taken from the PhysioNet database. Reconstruction of a topological 3D model of heart functioning and its spatio-temporal signatures are shown in Fig. 2a, b, c. Geometrization of the transformation of the cardiac cycle in the space of dynamic events is accompanied by a change in the structure of its components.

Note that any scalar time series $X(t)$ (digitized sensor signal, etc.) can be converted into a topological 3D model of the functioning and three signature packages. Their configurations are distinguished by the spatial ordering of the components and the time interval between events [11-15]. This allowed, within the framework of the new approach, to unify the tools for its implementation. 


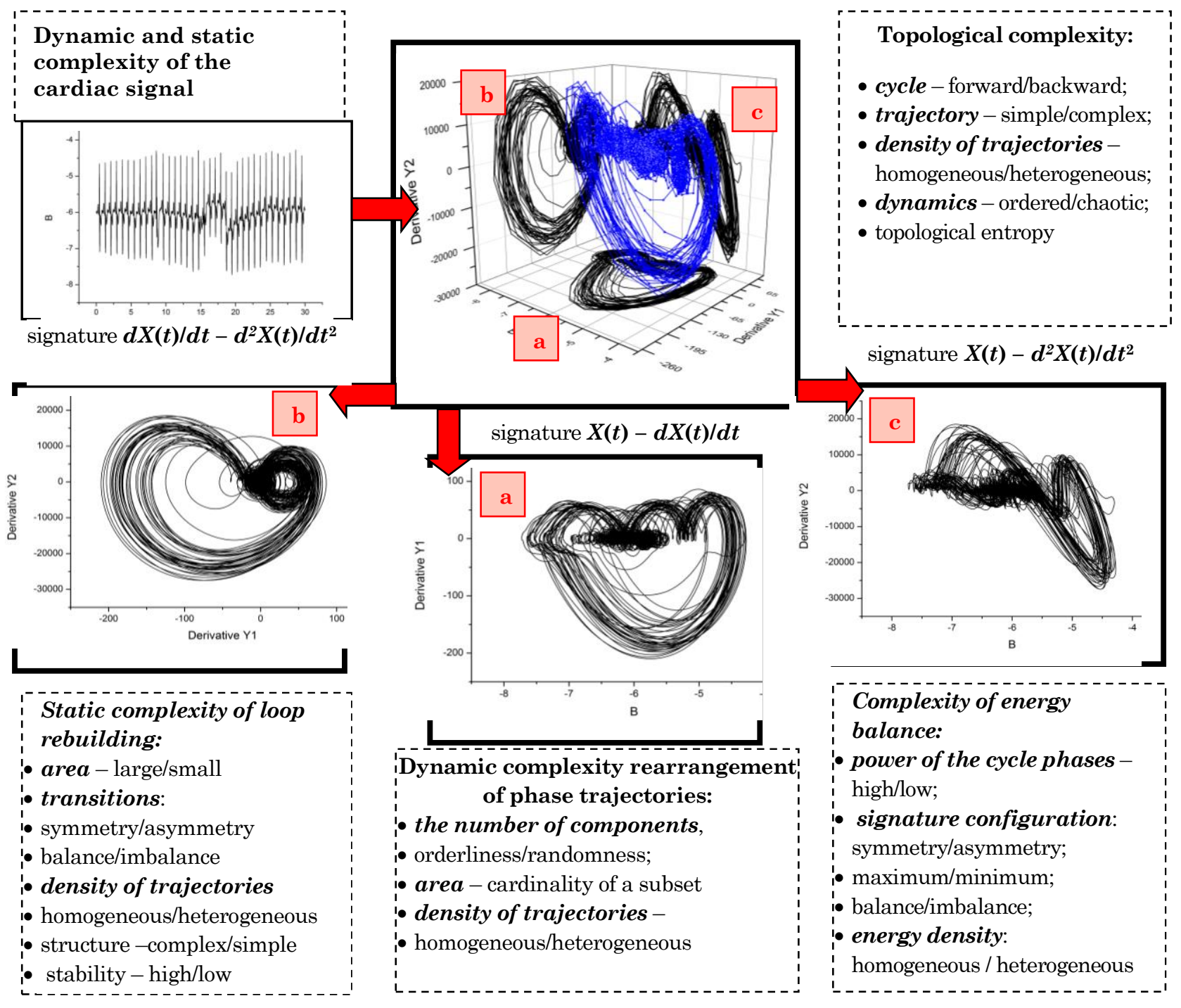

Fig. 2 - Topological 3D model of functioning and its signatures

The psychophysiological state of a person is displayed in the aggregate of electrophysiological signals (ECG, EEG, EOG, etc.) [16]. Desynchronization of the functioning of the subsystems of the human body is manifested in an increase in the dynamic and static complexity of the 3D model of the functioning and their signatures. Their configurations reflect: a) opposite processes of the cycle of functioning; b) geometrically ordered configuration components [11]. A holistic perception of the complexity of the signature configuration as a set of components that cover a certain area is more informative. It allows you to analyze simulation results using deterministic and statistical methods in real time [12-15]. At the same time, the use of the Shannon, Kolmogorov and Renier entropies simplifies the system analysis [5].

\section{RESULTS}

The configuration of the topological 3D model of functioning of sensors of different nature reflects the nature of the distribution of local distortions in the time signal (jumps, steps, fluctuations, etc.). The rela- tionship of these distortions with spatial inhomogeneities (defects) of a semiconductor sensor or optical information transmission environment has been established [17]. The nature of the rearrangement of interconnections of spatial and temporal local distortions in quasiperiodic fractal signals (responses of sensors, sensors, biosensors, etc.) determines their structural complexity. Topological modeling of the functioning of sensors of different nature and optical media for information transmission made it possible to relate spatial inhomogeneities with the features of the structure of time series (signals). This connection is reflected by the opposite components of the configurations of spatiotemporal signatures of the $1^{\text {st }}$ and $2^{\text {nd }}$ orders [17]. In the peculiarities of the interconnections of the components, the principles of biomimicry, artificial intelligence and metaphysics are manifested [18-20].

The area of signatures of the information source is proportional to the power of subsets of microstates, the natural logarithm of which is the Boltzmann entropy [11]. The individuality of configurations is caused by local inhomogeneities of electromagnetic continuous media. Therefore, the evolution of the spatio-temporal 
structure of the fractal signal most fully reflects the change in the configuration of signatures, as well as the change in the density of signatures in opposite phases of the cycle. Consequently, the cognitive information is given by the features of dynamics (stability, etc.), as well as the degree of compression of signatures in the package.

The geometric similarity of the constituent configurations of signatures of various sources of information (sensors, detectors, and also electrophysiological signals of a person taken from the PhysioNet database) has been established [35]. Therefore, the signature packets of human electrophysiological signals contain cognitive information about the nature of the rearrangement of their structure, the features of which are manifested in the change in the density of trajectories.

\section{DISCUSSION}

The cognitive simplicity of a topological 3D model of functioning is associated with the decomposition of the signal into opposite components, which are characterized by spatial and temporal ordering. As can be seen from Fig. 2, simplicity of spatio-temporal relationships was most evident in orthogonal projections of the 3D model of the multifractal cardiac signal. The individual character of the rearrangement of configurations transforms these projections into packages of spatiotemporal signatures of the $1^{\text {st }}$ and $2^{\text {nd }}$ orders [17].

A change in configuration is perceived as a whole as a change in the shape of opposite components, as well as a change in the area of quadrants (cardinalities of subsets). Therefore, the analysis of the rearrangement of their constituent configurations by complementary deterministic and statistical methods makes it possible to reveal the latent structure of the cycle of functioning. All this simplifies the cognitive perception of the topological 3D model of functioning.

The application of complementary extreme principles of mechanics to self-organized dynamic systems (intelligent sensors, intelligent materials, etc.) made it possible to identify an increase in structural complexity in their signals $[11,17]$. As can be seen from Fig. 2, the influence of stress factors is manifested in the nature of the restructuring of the cardiac cycle, which is caused by local distortions of the human electrocardiogram.

Cognitive problems (perception, presentation and distortion of information) are caused by a variety of a) sources of information, methods, parameters and criteria; b) means of processing and analyzing information flows; c) types of cognitive graphics. The consequence of this is the practical absence of indicators that reflect the individuality of the functioning of the information source (sensor, biosensor, etc.). This leads to difficulties in choosing the relevant information sources that are most sensitive to stress factors. In our opinion, the natural reconstruction of the topological $3 \mathrm{D}$ model of the functioning of a dynamic system from a measured fractal signal allows us to overcome the increasing structural complexity of modeling real dynamic systems.

As can be seen from Fig. 2, local distortions of the multifractal cardiac signal increase the dynamic and structural complexity. However, these distortions in the space of dynamic events are transformed into ordered components, which reduces all kinds of complexity. Thus, cognitive visualization of real signal distortions makes it possible to analyze all types of complexity. Visualization of hidden spatio-temporal features of human electrophysiological signals demonstrates the advantages and validity of the convergent approach to topological modeling of the functioning of self-organized environments (intelligent materials, information transfer, etc.). Evaluation of the complexity of trajectories in a batch representation of orthogonal projections of a 3D model of a fractal signal makes it possible to evaluate topological entropy visually in real time. For humancomputer interaction, it is important that the analysis of topological 3D models of the evolution of fractal signals can be supplemented by the analysis of three signature packages. This stimulates the active work of both hemispheres of the brain [2,3], which simplifies cognitive perception and presentation of information flows of different nature. Therefore, topological 3D models of functioning will expand the capabilities of machine learning, as well as intellectual support systems.

\section{CONCLUSIONS}

A convergent approach to modeling the functioning of self-organizing objects of different nature and a unified toolkit for its implementation are proposed. It is shown that the topological 3D model of the functioning of a selforganized information source reflects the features of its structural properties. Their individuality is determined by local signal distortions (jumps, fluctuations, etc.). They are due to the spatial inhomogeneities of the environment, the impact on which generates temporal inhomogeneities. Therefore, visualization of opposite signal components in the space of dynamic events provides cognitive information, which makes it possible to investigate structural properties in real time.

Analysis of the 3D topological model and spatiotemporal signatures using probabilistic and deterministic methods simplifies the identification of induced relationships. Therefore, the creation of an atlas of topological 3D models of fractal signals of different nature will accelerate the search for relevant information sources in complex dynamic systems (human organism, nuclear reactor, etc.).

\section{REFERENCES}

1. J.R. Fedota, R. Parasuraman, Theor. Iss. Ergonom. 11 No 5, 402 (2010).

2. V. Mygal, G. Mygal, Information \& Security: An International Journal 43 No 2, 134 (2019).

3. V.P. Mygal, G.V. Mygal, L.M. Balabanova, J. Nano- Electron. Phys. 11 No 2, 02013 (2019).

4. H. Haken, Principles of Brain Functioning. A Synergetic Approach to Brain Activity, Behavior and Cognition (Springer-Verlag Berlin Heidelberg: 1996).

5. G.V. Vstovskij, Elements of Information Physics (M.: MGIU: 2002) [In Russian].

6. M. Roco, W. Bainbridge, Converging Technologies for Im- 
proving Human Performance: Nanotechnology, Biotechnology, Information Technology and Cognitive Science [Electronic resource].

7. V.P. Mygal, G.V. Mygal, J. Nano- Electron. Phys. 12 No 6, 06018 (2020).

8. N.H. Packard, J.P. Crutchfield, J.D. Farmer, R.S. Shaw, Phys. Rev. Lett. 45, 712 (1980).

9. F. Takens, Nonlinear Dynamics and Turbulence. N.Y, Pitman, 314 (1983).

10. M. Schwaninger, J. Ríos, System Dynam. Rev. 24 No 2 , 145 (2008).

11. V.P. Mygal, A.V. But, G.V. Mygal, I.A. Klimenko, Sci. Rep. 6, 387 (2016).

12. M. Stolzner, Studies in the History of Modern Physics 34, 285 (2003).
13. J.Katzav, Analysis 64 No 3, 206 (2004).

14. V. Terekhovich, Studies in History and Philosophy of Science Part B: Studies in History and Philosophy of Modern Physics 62, 189 (2018).

15. G. Georgiev, Self-Organizing Systems. Lecture Notes in Computer Science 7166, 90 (2012).

16. A.W.F. Edwards, Philosophy of Biology (Elsevier B.V.: 2007).

17. V.P. Mygal, A.V. But, A.S. Phomin, I.A. Klimenko, Semiconductors 49 No 5, 634 (2015).

18. M. Passino Kevin, Biomimicry for Optimization, Control, and Automation (Springer-Verlag: 2005).

19. J.S. Russel, S. Norvig, Prentice Hall (New Jersey: 2003).

20. S. French, The structure of the world. Metaphysics \& Representation (Oxford University Press: 2014).

\title{
Топологічна 3D модель функціонування динамічної системи - когнітивне оцінювання складності
}

\author{
В.П. Мигаль, Г.В. Мигаль
}

Національний аерокосмічний університет ілені М.Є. Жуковського "Харківський авіаційний інститут», вул. Чкалова, 17, 61070 Харків, Україна

Стаття присвячена складності моделювання функціонування динамічних систем різної природи (сенсори, детектори, інтелектуальні матеріали та інші джерела інформації). Дія факторів стресу навколишнього середовища або діяльності збільшуе статичну складність джерел інформації, що призводить до динамічної складності. Інформація про це міститься в структурі індукованих взаемозв'язків, прихована складність яких обмежуе можливості прогнозування функціонування динамічної системи в реальному часі. Мета роботи - когнітивна візуалізація функціонування різних джерел інформації. Морфологічно різні динамічні системи функціонально підкоряються одним і тим же екстремальним принципам фізики, а досліджуються динамічними і статистичними методами. Їх взаємодоповнюваність дозволила уніфікувати реконструкцію тривимірної топологічної моделі функціонування джерела інформації за вимірюваним фрактальним сигналом. Встановлено, що прихована структура сигналу визначається просторовими неоднорідностями, які породжують неоднорідності в часі джерела інформації і середовища передачі. Фактори стресу збільшують складність просторово-часових сигнатур, що дозволяе оцінити складність їх конфігурацій по збільшенню кількості складових і охопленій площі. Тому структура фрактального сигналу може бути проаналізована в реальному часі з використанням взаемодоповнюючих імовірнісних та детермінованих методів. Створення атласу сигнатур фрактальних сигналів спрощуе ідентифікацію та класифікацію джерел інформації різної природи. Його використання зменшить когнітивні проблеми, які пов'язані зі складністю та розширить набір інструментів прогнозної аналітики. Візуалізація прихованих просторово-часових особливостей електрофізіологічних сигналів демонструе переваги і обгрунтованість когнітивної візуалізації функціонування різних підсистем організму людини.

Ключові слова: Динамічна складність, Фрактальні сигнали, Прихована структура, Топологічні моделі, Просторово-часові сигнатури. 